\title{
日本城镇海啸避难所规划策略研究
}

\section{Study on Strategy of Tsunami Refuges Planning in Japanese Towns}

摘要: 以日本大地震“地震一海啸一核泄漏事故”这一重大复合 灾害为背景, 通过对日本城镇海啸避难所规划策略的研究, 一方 面归纳出海啸避难所定义与类型、海啸避难场所规划设计方法和 发展策略, 另一方面探讨了日本法律背景下的疏散计划框架。我 国沿海城市灾害类型多且频繁发生, 但避难疏散场所建设及防控 措施单一而薄弱。本文力图弥补当前我国避难场所的课题研究的 空白, 系统化完善避难疏散场所规划体系, 有效预防、减少和消 除灾害损失, 以期对我国沿海城市避难疏散场所提供实效性较强 的规划策略和启示。

Abstract: Taking Great East Japan Earthquake which is an "earthquaketsunami-nuclear leakage accident" compound disaster to analyze the planning strategy of tsunami refuges in Japanese towns, the article sums up the definition, types, planning method and development strategy of tsunami refuges, and explores the evacuation framework under the legal background of Japanese. Various types of disasters occur frequently among Chinese coastal cities, but the prevention and control measures for refuges in those cities are less and weak. The study aims to make up for the lack of research of refuges in China, to perfect the planning system of refuges systematically, to prevent, reduce and eliminate the loss caused by disasters effectively, and to provide an enlightenment of effective planning strategies for refuges of Chinese coastal cities.

关键词：海啸避难所；沿海城市；防灾减灾

Keywords: Tsunami Refuge; Coastal City;

Prevention and Reduction of Disaster

天津市哲学社会科学规划研究项目 “大数据背景下天津城市灾害 风险防治对策研究” (TJGLQN17-004) 成果

作者: 王港, 天津大学建筑学院博士, 天津城建大学建筑学院讲师。 gniygnaw2006@126.com 曾坚, 天津大学建筑学院, 教授 王强, 天津大学建筑学院, 教授

\section{引言}

根据国际灾害数据库（Emergency Events Database）提供的数 据统计 ${ }^{11}$, 对日本 1950-2014 年 64 年间发生的自然灾害进行分 析和挖掘。研究表明, 日本对防灾减灾的重视由来已久, 在历史 经验与法律体系的衔接与协调中, 最大限度地提升应对灾害的能 力, 提高救灾效率, 有序推进避难疏散场所的建设。1978 年以后, 灾害直接影响人数与总波及人数陡然下降（图 1), 政府防灾减灾 的措施和行动挽救人民生命和财产安全, 取得了卓有成效的成果。 1980 年, 随着城市化进程的推动, 日本经济经历飞速增长。然 而, 高强度的土地开发、高密度的城市空间环境、高速率的信息 交换和高聚集的人群正在深深改变着城镇自然山水地理格局, 城 镇的承载极限不断增大, 更容易遭受灾害影响。2011 年 3 月 11 日, 日本东北部海域发生里氏 9.0 级地震, 继而引发海啸, 造成福岛 第一核电站发生核泄漏, 波及 $600 \mathrm{~km}$ 的海岸线。避难疏散场所每 日收容能力已接近上限, 曾达到 55 万人。地震发生后第 6 天, 8 个县的 2400 多处避难设施中容纳约 43 万人; 地震发生后第 9 天, 仍有 2100 处避难设施容纳约 37 万人。此次复合灾害所造成的经 济损失高达约 2100 亿美元, 占 2011 年度全球损失总额的 57\% ${ }^{\mid 24}$ (图 2)。如此浩劫带给人们的是心有余悸和铸就伤痛的记忆犹新, 研究此次灾害具有典型性。

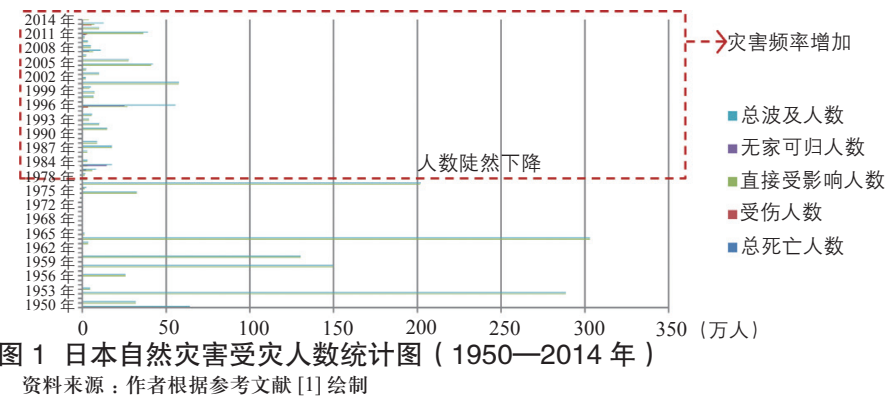




\section{1 日本城镇海啸避难所}

在灾害突变和渐变相互转变的过程中, 城镇自然生态与 致灾因子之间进行着物质、能量和信息的交换, 与人类的工 程活动、经济社会的发展密切相关。“地震一海啸一核泄漏 事故” 这类过去不为人预知的复合灾害突发, 凸显了灾害的 不确定性和开放性, 地震后的海啸避难疏散困难直接导致了 灾民的死亡。因此, 研究疏散与避难场所的布局设置, 建立 相对完整的避难疏散体系, 才能确保逃生行动与避难生活的 有序进行。

\section{1 避难疏散场所等级与类型}

自江户时期日本建立避难小屋提供救助, 至今已经初具 避难所雉形 ${ }^{[5]}$ 。从此以后, 日本针对多种灾害, 按照应急机 制与灾害影响, 经过科学的规划设计和合理的建设, 配备相 应完善的配套设施。日本城镇中避难疏散场所基本上可分为 三个等级：临时集合场所、避难场所和避难所（表 1)。

\subsection{1 避难场所}

根据日本广岛西南部吴市的危机管理部门的分类, 避难 场所基本上包括三种类型 : 广域避难场所、临时避难场所和 临时避难设施, 以城市的绿地、公园、广场等开敞空间为主。

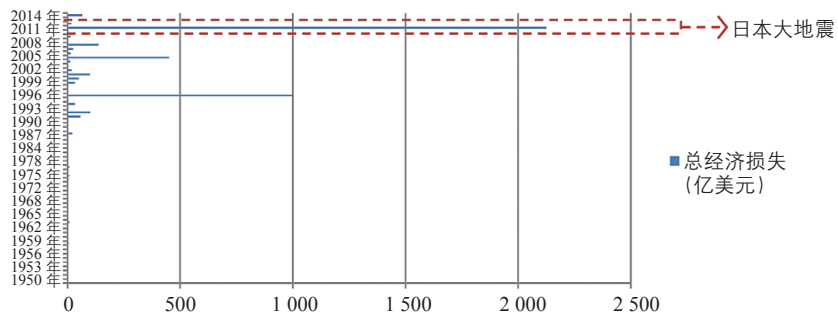

图 2 日本自然灾害经济损失统计图（1950-2014 年） 资料来源 : 作者根据参考文献 [1] 绘制

表 1 日本城镇避难场所分类

\begin{tabular}{|c|c|c|}
\hline 按照等级分类 & 按照类型分类 & 功能 \\
\hline 临时集合场所 & 临时集合场所 & $\begin{array}{l}\text { 通常用于转移灾民到安全庇护和临时避 } \\
\text { 难的过渡性场所 }\end{array}$ \\
\hline \multirow{3}{*}{ 避难场所 } & 广域避难场所 & \multirow{3}{*}{$\begin{array}{l}\text { 通常用于灾民紧急疏散, 或者临时生活 } \\
\text { 安置的开敞空间 }\end{array}$} \\
\hline & 临时避难场所 & \\
\hline & 临时避难设施 & \\
\hline \multirow{5}{*}{ 避难所 } & 避难据点 & \multirow{5}{*}{$\begin{array}{l}\text { 通常用于提供给无家可归的灾民中长期 } \\
\text { 居留的公共建筑 }\end{array}$} \\
\hline & 准避难据点 & \\
\hline & 福利避难所 & \\
\hline & 准福利避难所 & \\
\hline & 地区避难所 & \\
\hline
\end{tabular}

（1）广域避难场所：收容灾民, 并确保其安全的大面积 场所。

（2）临时避难场所：临时提供给较多灾民避难的大面积 场所, 当灾害险情得到控制后, 可向广域避难场所转送。

（3）临时避难设施：为了躲避洪水、风暴潮、海啸等 灾害威胁, 滞留的灾民在中、高层建筑的室内、建筑屋顶、 走廊等临时避难的设施, 多为钢筋混凝土或钢结构的牢固 建筑。

1993 年, 日本结合防灾公园制定了《城市公园法实施 法令》, 将上述广域避难场所、临时避难场所和临时避难设施, 结合城市绿地、公园和广场细化分为六种类型, 并赋予技术 指标 (表 2)。

\subsection{2 避难所}

日本城镇避难所包括五种类型 : 避难据点、准避难据点、 福利避难所、准福利避难所和地区避难所。

（1）避难据点：城镇遭受地震、风灾、水灾等灾害, 或者受灾害威胁时, 民众暂时滞留的建筑物, 以中小学校 为主。

（2）准避难据点：在避难据点无法收容避难者时开放的 暂时滞留的建筑物。可根据灾害的种类、规模与避难据点一 起开放, 以大学为主。

（3）福利避难所: 为需要特别照顾的特殊人群临时滞留 而开放的建筑物, 以老人福利设施、无障碍设施等为主。

(4) 准福利避难所 : 为照顾轻度特殊人群开放的暂时滞 留的建筑物, 以及在避难据点等地的避难生活困难的情况下, 转送轻度需要照顾的特殊人群的地方。

（5）地区避难所：根据灾害的种类和规模, 地区自主 开放的临时滞留的建筑物, 根据避难者的需要向避难据 点或准避难据点转移, 以会馆、集会所、小区活动中心 等为主。

\section{表 2 日本结合防灾公园的避难疏散场所类型与特征}

\begin{tabular}{|c|c|c|c|c|}
\hline 类型 & 规模 & 空间载体 & 标准或建议性规定 & 作用 \\
\hline $\begin{array}{l}\text { 广域防灾 } \\
\text { 据点 }\end{array}$ & $\begin{array}{l}\text { 面积 } 50 \mathrm{hm}^{2} \\
\text { 以上 }\end{array}$ & $\begin{array}{l}\text { 郊野公园、自然 } \\
\text { 公园 }\end{array}$ & 50 万 $\sim 150$ 万人 & 阻隔灾害 \\
\hline $\begin{array}{l}\text { 广域 避 难 } \\
\text { 场所 }\end{array}$ & $\begin{array}{l}\text { 面积 } 10 \mathrm{hm}^{2} \\
\text { 以上 }\end{array}$ & $\begin{array}{l}\text { 广域公园 }{ }^{[6]} \text { 、都 } \\
\text { 市基干公园 }{ }^{[7]}\end{array}$ & 服务半径 $2 \mathrm{~km}$ & 安全停留 \\
\hline $\begin{array}{l}\text { 紧急避难 } \\
\text { 场所 }\end{array}$ & $\begin{array}{l}\text { 面积 } 1 \mathrm{hm}^{2} \\
\text { 以上 }\end{array}$ & $\begin{array}{l}\text { 街区公园、儿童 } \\
\text { 游园 }\end{array}$ & 服务半径 $0.5 \mathrm{~km}$ & 紧急避难 \\
\hline 避难道路 & $\begin{array}{l}\text { 宽 度 } 10 \mathrm{~m} \\
\text { 以上 }\end{array}$ & $\begin{array}{l}\text { 城市绿道、生态 } \\
\text { 廊道 }\end{array}$ & $\begin{array}{l}\text { 绿带宽度 } 10 \mathrm{~m} \\
\text { 以上 }\end{array}$ & 防止茵延 \\
\hline 缓冲绿地 & 不限 & 都市绿地 & 不限 & 阻隔灾害 \\
\hline $\begin{array}{l}\text { 邻近防灾 } \\
\text { 据点 }\end{array}$ & $\begin{array}{l}\text { 面积 } 500 \mathrm{~m}^{2} \\
\text { 以上 }\end{array}$ & $\begin{array}{l}\text { 近邻公园、宅旁 } \\
\text { 绿地 }\end{array}$ & 人均避难面积 $2 \mathrm{~m}^{2}$ & 迅速到达 \\
\hline
\end{tabular}




\section{2 海啸避难所}

日本 “ $3 \cdot 11$ ”东北大地震引发海啸, 横扫沿海地区, 曾建立在海边附近的地震避难场所顷刻间被海水吞噬, 大片 陆地被海水倒灌, 许多避难所和基础设施被摧毁, 根本无法 避难。原本供安全疏散的地震避难场所面临海啸反而成为危 险区域。尽管修建了防护堤坝, 建立了地震与海啸预警系统, 公布了疏散计划和开展公众宣传, 但部分地区浸水的高度和 波及范围仍然超过了预测。这些现象引发了日本相关部门的 高度重视和反思。为了完善应急机制, 2011 年 12 月政府针 对这次海啸灾害特别出台了《海啸防灾地区建设法》 ${ }^{[8]}$, 并 开始尝试在低海拔地区和避难困难地域建设海啸避难所。

针对地震引发的海啸及其引发的次生灾害, 如房屋倒塌 等, 海啸避难所可供较长时间停留 ${ }^{[9]}$, 分为海啸紧急避难所 和海啸长期避难所 (表 3)。

\section{3 规划设计方法}

基于海啸浸水预测图, 依据总务省消防厅 2003 年颁布 的《市镇村海啸避难规划制定指南》(以下简称《指南》) 对避难对象地域进行规划布局。根据历史经验震级最高、 破坏力最强的地震, 推测避难可能的时间, 即从地震发生, 避难疏散开始（即避难开始时间）, 到海啸到达为止的时间。 鉴于地震对道路造成的破坏, 如信号灯失效、避难车辆增多、 秩序混乱、有效避难道路狭窄等, 以及海啸速度快的特点, 灾民在短时间内的防御措施是步行至邻近处的高台。《指 南》建议的正常人逃生步行速度是 $1.0 \mathrm{~m} / \mathrm{s}$ (时速 $3.6 \mathrm{~km}$ ), 考虑到特殊人群 (老年人、残障人、孕妇等) 疏散行为特征, 确定避难速度以 $0.5 \mathrm{~m} / \mathrm{s}$ (时速 $1.8 \mathrm{~km}$ ) 为基准。以避难距 离为半径, 推算出避难所可能的设置范围和危险区域 ${ }^{[10]}$ (图 3)。依据城市空间布局特点确定避难路, 即城镇通往海啸 避难所的指定道路。海啸警报未解除前, 将民众疏散至海 啸紧急避难所和海啸避难所。当没有海啸危险的时候, 紧 急灾害对策本部把避难人员移送至远离海啸区域的避难所,
且为需要援助的老年人、残障者等特殊人群提出申请并护 送至福利避难所, 部分灾民将被转移到准避难据点。

\section{4 规划策略 \\ 1.4.1 建设海啸避难所}

日本政府指定的海啸疏散避难地点超过 7 万个, 包括避 难场所和避难所 ${ }^{[11]}$ 。这些避难地点部分设置于远离海啸浸水 区域, 在适宜的高地选址, 并具备良好的避难功能。在日本 “3 - 11” 东北大地震引发海啸吞噬的地域, 高层避难建筑 （构筑物）发挥了重要的作用，挽救了灾民的生命。日本仙 台市 5 个城镇至少 9700 人撤离至指定的坚固的高层建筑物 (构筑物), 从而得以幸存。海啸避难所专门设计用于减轻 海啸给灾民造成的威胁, 避免近海岸地区由于没有高地避难 而瞬间夺走居民生命。指定的海啸避难所, 应位于经过分析 预计的海啸淹没区域, 并具备足够的安全高度来抵御海啸对 灾民的威胁（图 4)。通过卫星图像空间分析, 从抗震设计 角度优化结构的各个部位, 模拟可经受最大级别海啸的海浪 冲击, 综合考虑整个建筑物在 “地震一海啸” 这类复合灾害

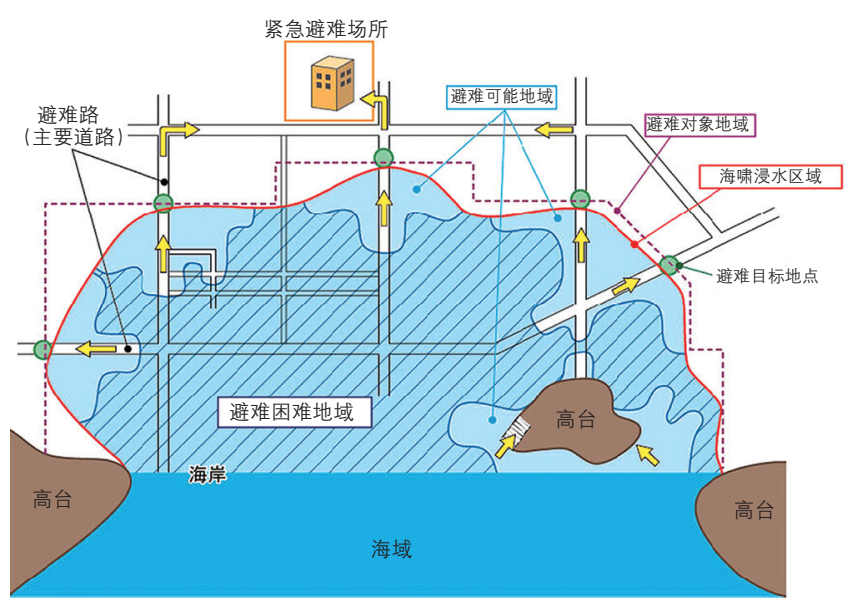

图 3 日本城镇海啸危险区域示意图

资料来源: 参考文献 [10]

\section{表 3 日本城镇海啸避难场所类型、定义及特征辨析}

\begin{tabular}{|c|c|c|}
\hline 分类 & 海啸紧急避难所 & 海啸长期避难所 \\
\hline 用途特征 & 紧急转移至安全处, 时间相对较短 & 安置回家困难灾民, 时间相对较长 \\
\hline 标准制定 & $\begin{array}{l}\text { 符合容纳受灾者紧急停留的适当规模; 结构坚固, 隔震减震, 也不会因海啸 } \\
\text { 灾害而损毁 ; 在有效避难时间内, 具有海啸水位以上高度的避难空间 } \\
\text { 除此以外还需满足以下的任何一条： } \\
\text { ·安全区域内避难场所（例如高塔等）; } \\
\text { ·安全区域外避难设施（例如海啸避难所） }\end{array}$ & $\begin{array}{l}\text { 符合容纳受灾者居住的适当规模; 有利于迅速接受受灾者; 有利于 } \\
\text { 迅速提供、分配救灾援助物资; 受海啸灾害的影响相对较小; 方便 } \\
\text { 救援车辆进出 } \\
\text { 除上述要求外, 还具备特殊人群（例如老年人、残障人、乳幼儿或 } \\
\text { 需要照顾的人）特殊避难设施和救援体制 }\end{array}$ \\
\hline 管理机制 & 由市长、镇长、村长指定 & 由市长、镇长、村长指定 \\
\hline 适用范围 & \multicolumn{2}{|l|}{ 必要时两者可以兼用 } \\
\hline
\end{tabular}


作用下的性状, 加强构造措施 ${ }^{[12]}$ 。人工建造的开放平台式垂 直避难所, 不一定是完全封闭的空间（表 4)。

\subsection{2 强化学校等教育设施的防灾功能}

日本 “ $3 \cdot 11$ ” 大地震后, 中小学教室和体育馆均成为 避难所。由于学校建筑物防灾建设标准要求高, 相对最为安 全, 灾害来临时多数灾民选择去学校操场和教室避难。2011 年 7 月, 日本颁布《关于东日本大地震受灾学校设施管理条 例》, 提出学校需根据所在位置区域情况提出相应的应对策 略。2012 年 1 月, 日本文部科学省对学校作为避难所的利 用状况进行课题研究, 统计出福岛县和宫城县（除仙台市以 外） 525 所学校避难利用的现状和问题。日本东北部大地震 避难所利用的学校设施中，体育馆利用率高达 $70.1 \%$, 普通 教室利用率为 $34.9 \%$, 特别教室利用率为 $33.3 \%$, 空教室利 用率为 $21.7 \%$ 。调查中还发现, 学校内的厕所、取暖设备、 给水设备、通信设备和供电设备等多数存在问题 ${ }^{[14]}$ 。截至 2013 年 5 月, 日本用于灾时避难所的学校数量为 32202 所, 占全国公立学校总数 $92 \%$, 其中 $90.3 \%$ 是中、小学校, 另外 还有高等学校、中等教育学校和其他学校。

由此可见, 学校教育设施在灾时避难疏散过程中起到了

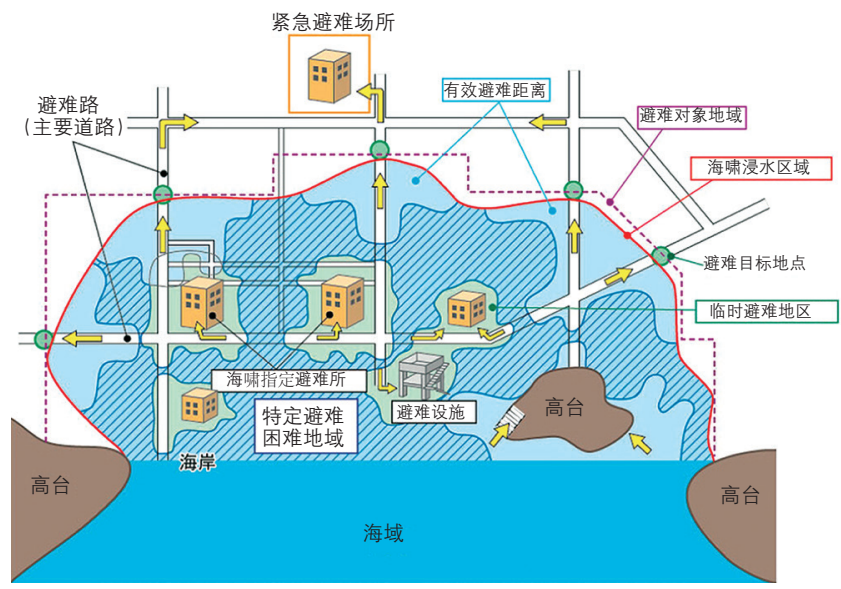

图 4 日本城镇海啸灾害疏散方案 资料来源 : 参考文献 [10]

表 4 日本海啸避难所设计标准

\begin{tabular}{l|l}
\hline \multicolumn{1}{c|}{ 项目 } & \multicolumn{1}{c}{ 标准说明 } \\
\hline 安全高度 & $\begin{array}{l}25 \mathrm{~m} \text { 左右 (约 } 6 \text { 层楼高度) } \\
\text { 海啸避难所安全高度 }=(\text { 最大海啸海浪波高 } \times 1.30)+1.0 \mathrm{~m}\end{array}$ \\
\hline 规模 & 紧急避难所可容纳 300 人, 普通避难所可容纳 100 人 \\
\hline 建筑物抗灾级别 & 抗震 ; 可经受最大级别海啸的海浪冲击 \\
\hline 防灾设备 & 海啸监控摄像头、救援物资储备仓库、紧急发电设备等 \\
\hline 其他设备 & 电梯、给排水设备 \\
\hline
\end{tabular}

资料来源 : 根据参考文献 $[9,13]$ 整理
至关重要的作用。在充分考虑避难人数的情况下，假设海啸 灾害地域存在学校等教育设施, 应该强化学校的防灾功能, 了解学校用地标高、到海岸或河岸的距离、周围的地形情况, 以及历史上遭受海啸灾害到达地域、到达时间等资料, 使 实际状态符合制定的避难所标准（图 5, 图 6)。

\subsection{3 建设海啸紧急避难设施}

高地和山坡上的建筑均能成为紧急避难所。根据不同地 形形成两种策略, 即建设海啸避难台阶和避难通道, 以通往 山坡上的高地和建筑进行避难, 最大限度地赢得时间, 挽救 灾民的生命（表 5)。

\section{2 日本依托相关法律的海啸疏散框架}

日本拥有世界上最为先进的预警系统一收集各种地震 和海啸信息，通过媒体、综合防灾系统、全国瞬时警报系统 (Japan Alert System)、网络、手机短信等一切手段迅速详细 地向民众传达。该预警系统将海啸海浪高度分类, 确定海啸

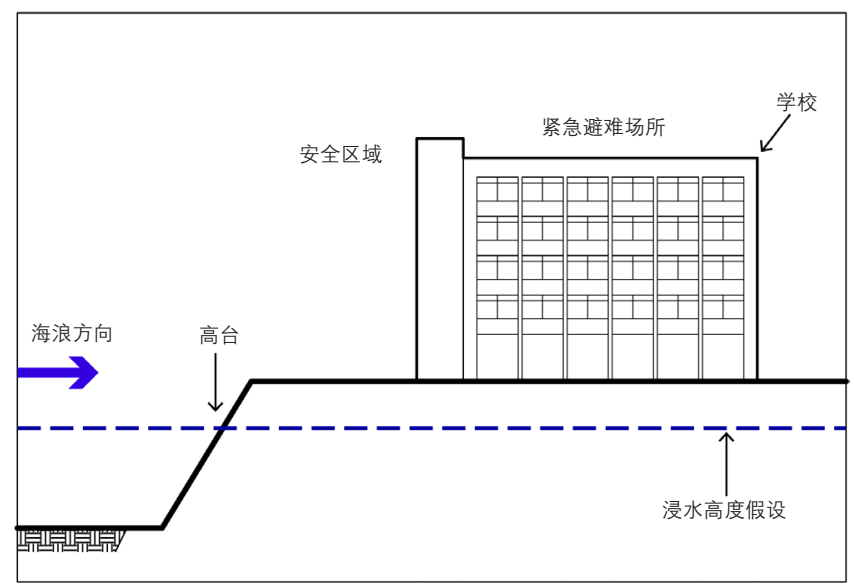

图 5 高地上的学校作为紧急避难场所

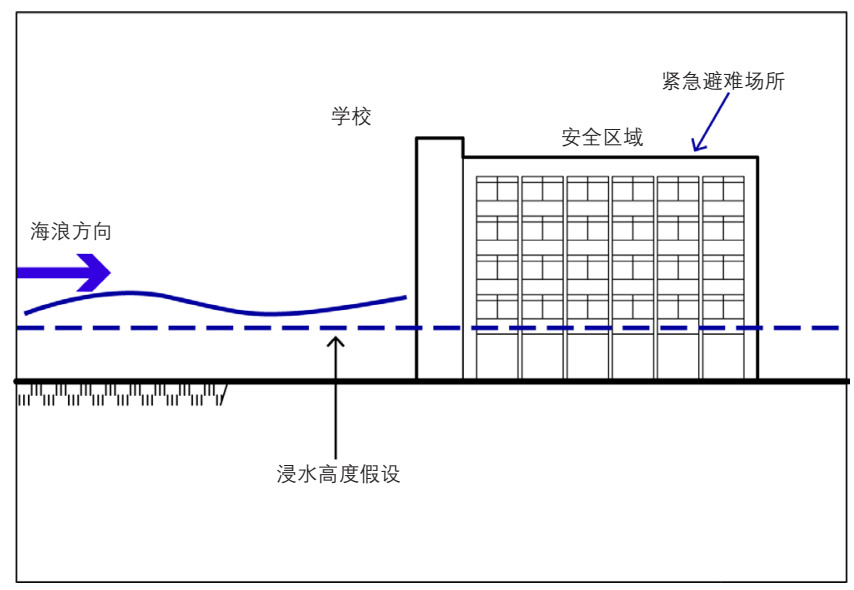

图 6 学校屋项平台作为紧急避难场所 
警报的等级。当预测海啸高度超过 $3 \mathrm{~m}$ 时, 启动重大海啸警 报; 当预测海啸高度在 1 3 $\mathrm{m}$ 之间时, 启动海啸警报; 当预 测海啸高度在 $0.2 \sim 1 \mathrm{~m}$ 之间时, 进行海啸通报。

2010 年, 参考地震疏散计划, 日本又制定了水灾疏散 计划的疏散框架, 以及浸水区域周边对象的市（镇、村）地 域防灾计划。根据同年修订的《灾害对策基本法》防灾规划 第 3 5 条规定, 中央政府负责制定国家防灾计划, 并对自治 体进行防灾工作的推进和综合调整。都（道、府、县）制定 并实施都 (道、府、县) 所在地相关的防灾规划, 负有对本 都（道、府、县）内的市（镇、村）进行的相关防灾援助和 综合调整的责任。市（镇、村）等 “基础自治体”负责制定 地方行政单位防灾相关的规划并负责实施。其中第 2 条还规 定了市（镇、村）防灾协作互助的框架, 对于实施防灾对策 有实际困难的或者没有效果的情况, 都（道、府、县）或市 （镇、村）等 “基础自治体” 可采取跨越行政区的协作计划, 制定受灾地域整体的援助对策。

\section{3 对我国沿海城市避难场所规划的启示}

我国漫长的海岸线集中了很多重要的经济地区, 一旦发 生危险后果将不堪设想。为了确保沿海城市防灾规划战略地 位的优先性, 在沿海存在灾害风险的地区, 确定相关避难疏 散规划研究具有重要意义。

\section{1 系统化完善避难疏散场所规划体系}

避难疏散场所规划应该是一个系统化的规划类型, 以战 略的思维审视城市的安全问题, 防止规划条例重叠却针对性 不强, 内容交叉却衔接不利。积极确定合理的城市空间布局、 功能结构、空间形态和防灾设施, 探索理想的防灾空间秩序, 并作为编制城市总体规划的依据。控制灾害的扩散, 对于减 少由此产生的次生灾害, 立足长远地消除灾害隐患和改善城 市生态环境有积极推动的作用。有效地组织安排灾民避难是 一个非常复杂的问题, 必须把影响沿海城市疏散的问题提升 到较高的视角去思考, 进行全局性、综合性、战略性的谋划,
强调避难场所专项规划在城市总体规划中的作用, 弥补突发 公共事件可能导致的综合防灾在任何环节上滞后或失效, 作 出正确的应对, 防患于未然。促使城市防灾要求和措施融人 城市分区规划、详细规划等城市不同类别不同层次的规划, 实现城市避难疏散的高效、规范、有序运行, 切实增强城市 的应变能力 (图 7)。

\section{2 弥补避难场所课题空白}

我国沿海城市集中了大量的经济活动、就业机会和创新 中心 ${ }^{[15]}$, 一旦发生复合灾害, 疏散集聚人群至相对安全的避 难场所是减少人员伤亡和财产损失的唯一途径。因此, 沿海城 市不同种类避难疏散场所的选址和规划布局是解决城市安全 问题首先面对的重大课题。避难场所类型必须应对不同致灾因 子的特性与来源、灾害产生影响程度和避难功能的需求, 逐步 深人到具体的建设措施、指标体系等方面（表 6), 并制定相 应的优化疏散行动措施。与日本相比, 我国避难场所防范灾种 类型和功能相对单一, 从现有的应急避难场所统计分析, 重点 基于应对地震这一灾种安置受灾者, 建设避震疏散场所, 且类 型与层级结构的分类方法相对模糊, 整体缺乏针对性。

\subsection{1 针对自然灾害类型建设避难场所}

沿海城市多发生海洋、气象、洪涝、地质灾害与地震等 自然灾害, 由于缺少面对变化莫测的灾害风险概念和灾害演 化规律的相关思考, 缺少针对沿海城市多发的自然灾害而建

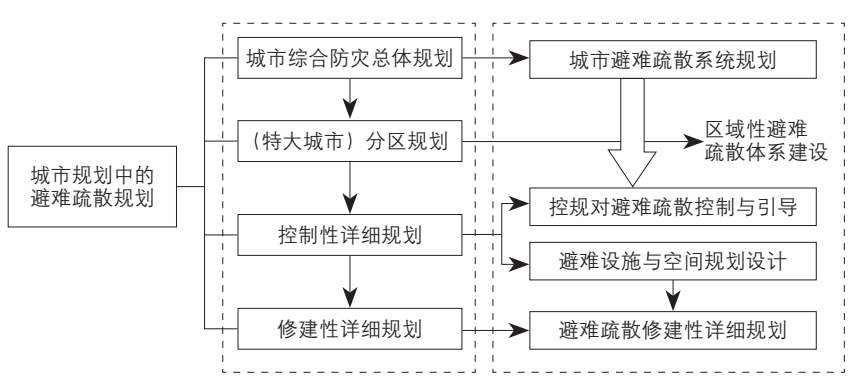

图 7 避难疏散场所规划体系

\section{表 5 海啸避难台阶和避难通道}

策略一; 避难台阶


设的避难场所, 在面临灾害错综复杂与次生灾害连锁频发时, 无法满足灾民的避难需求。2015 年 7 月浙江沿海遭遇 50 年 来最严重台风“灿鸿”, 造成城市内涝、山体滑坡等复合灾 难, 沿岸地区 115 万人紧急疏散 ${ }^{[16,17]}$ 。如果有针对台风、暴雨、 风暴潮等沿海城市自然灾害而建设的避难场所, 就可以提高 城市的应急避难能力, 有效加快政府灾害应急机制, 为危险 中的人们及时、适时提供安全保障, 避免大范围、大规模民 众因长途疏散的困难陷人恐慌, 成为呵护生命之所在。

（1）构建沿海城市海洋型、气象型避难场所

构建海洋型避难所。由于海啸预报难度很大, 且并不是 所有海啸都必定引发地震, 常被认为是小概率事件。然而,

\section{表 6 我国沿海城市避难场所与避难所构建}

\begin{tabular}{l|l}
\hline \multirow{4}{*}{ 灾害种类 } & 气象型避难场所 \\
\cline { 2 - 2 } & 海洋型避难所 \\
\cline { 2 - 2 } & 地质型避难场所 \\
\cline { 2 - 2 } & 人防工程避难所 \\
\hline \multirow{2}{*}{ 灾害产生影响 } & 场地型避难场所 \\
\cline { 2 - 2 } & 场所型避难场所 \\
\hline \multirow{4}{*}{ 避难功能 } & 地上垂直避难所 \\
\cline { 2 - 2 } & 地面避难场地 \\
\cline { 2 - 2 } & 地下避难所 \\
\hline
\end{tabular}

我国周边海域大多位于环太平洋地震带上, 如南海东部、菲 律宾以西海域, 一旦发生地震就可能引发传至浅海的巨浪, 使周边沿海城市处于危险的境地, 甚至可能直接引起海啸灾 害, 海南、广州、福建、浙江和港澳台等沿海省（市）便会 受到波及，人民的生命和财产面临严重的威胁。

构建气象型避难场所。全球气候变暖引发的暴雨、洪水 等灾害和极端气候事件与日俱增。天津市有应急避难场所 28 个, 总计占地 431.1 万 $\mathrm{m}^{2}$, 共可容纳 118.9 万人。 2012 年 7 月天津遭遇 1978 年以来特大暴雨及洪涝灾害 ${ }^{[18]}$, 长虹公园、 水上公园等避难场所使用率偏低, 并不适合暴雨灾害避难, 再次引发人们对基于避震建设的疏散场所无法适合其他种类 灾害的思考。

\section{（2）优化沿海城市地震避难场所指标}

我国是一个地震灾害多发的国家, 由于自然地貌丰富多 样, 不可能在应急避难方面制定统一的规范标准。因此, 上 海、深圳和台北等沿海城市相继制定了地方应急避难设计规 范和规划纲要 ${ }^{[19-22]}$ (表 7)。沿海城市贯彻执行国家标准的同 时, 需要进一步寻求适用于本地的避难场所设计方法和途径, 从满足城市安全的角度来控制指标的科学性, 与控制性详细 规划指标体系相结合。同时, 城中村、棚户区、城乡结合部 需确定相应的避难疏散改造模式和改造时序, 形成从粗放破

表 7 沿海城市避震场所技术指标类比

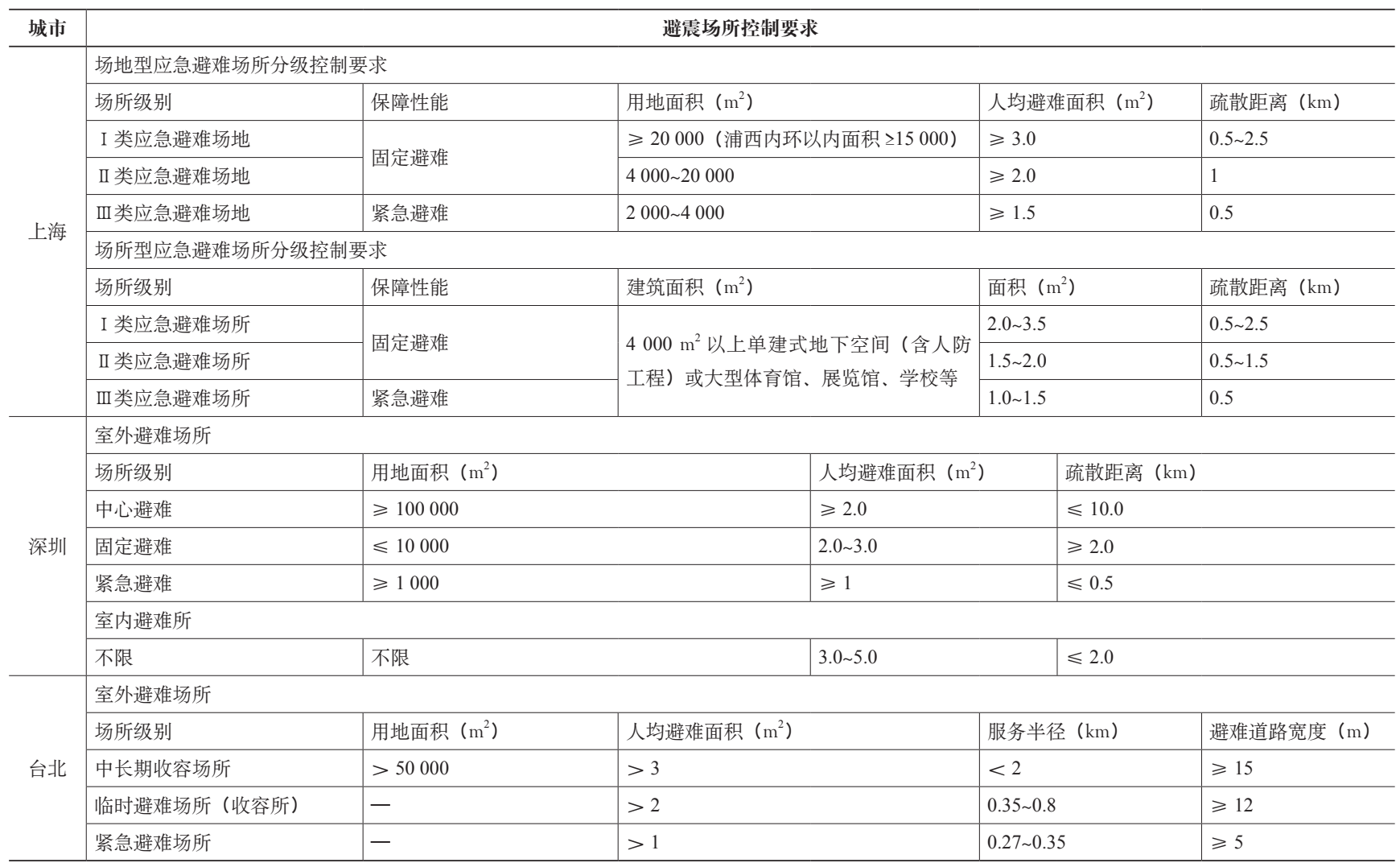


碎到统筹有序的避震场所指标优化策略 ${ }^{[23]}$ 。根据沿海城市中 心城区传统的街巷空间尺度及其连续性, 提出防灾措施, 并 结合人的疏散行为, 在充分认知环境空间的基础上选取疏散 指标数值的参考值。

\subsection{2 针对人为灾害特征建设地下避难所}

人为灾害与自然灾害往往密不可分, 人类的活动可能诱 发自然灾害或加重灾害, 突发的自然灾害也可能引起人为次 生灾害或衍生灾害。本文所指人为灾害分为两种类型：一种 是人为事故性灾害, 另一种是人为故意性灾害 ${ }^{[24]}$ 。其中, 人 为事故性灾害包括危险化学品泄漏、爆炸、火灾等; 人为故 意性灾害包括恐怖袭击、战争、社会骚乱等。

基于民防工程发展的视角, 国家经济越发达, 其城市避 难疏散功能越完善, 特别重视人防建设与地下防护空间的统 筹。一方面提高城市整体防卫能力, 发挥地下空间的抢险救 援和防灾救灾的特性; 另一方面提高城市抗御自然灾害和防 空抗毁能力, 应对地面建筑或基础设施被严重毁坏, 保存城 市部分功能, 提供灾时避难空间, 储备救援物资仓库, 开辟 救灾安全通道等。同时, 由于城市对土地的需求不断增加, 城市开发已从单一的地上发展转为立体化综合发展。地下交 通设施、地下商业设施、高层建筑地下空间、地下车库和地 下仓库设施等地下公共空间相继出现, 向地下要土地、挖掘 地下空间成为沿海城市发展避难所的必然趋势。

\section{4 结语}

目前, 国内避难场所规划针对 “地震一海啸” 这一特定 高风险海洋灾害的研究相对匮乏, 日本城镇海啸避难所规划 以崭新的视角, 为我国沿海城市避难疏散规划提供了参考理 念和实践目标, 开拓了避难疏散场所设计方法和思路, 并在 此基础上系统化完善避难疏散场所规划体系的构建, 为实现 沿海城市避难场所与防御各类灾害的契合提供了具体可操作 的途径。尽管如此, 避难疏散仍是一个多学科交叉的、复杂 的系统工程, 仍有多技术问题以及相应的保障机制方面的问 题, 需要在未来进行不断深人的探索和研究。UPI

注: 文中未标注来源的图表均为作者整理或绘制。

\section{参考文献}

[1] EM-DAT. Natural Disasters of Japan[DB/OL]. The International Disaster Database, Centre for Research on the Epidemiology of Disasters-CRED. (2015-06-06). http://www.emdat.be/advanced_search/index.html .

[2]王忠会. 日本 43 万人仍在避难, 已确认 4164 人死亡 7843 人失踪 [EB/ OL]. 中国新闻网 . (2011-03-16). http://www.chinanews.com/gj/2011/0316/2911182.shtml.

[3] 福岛避难所 21 名灾民死亡, 一名 80 岁老人丧命 [EB/OL]. 搜狐新闻.
(2011-03-19). http://news.sohu.com/20110319/n279893026.shtml.

[4] 王珊。日本 $3 \cdot 11$ 大地震占全球 2011 年间灾害损失近六成 [EB/OL]. 国际在线. (2012-10-17). http://gb.cri.cn/27824/2012/10/17/6071s3890315. htm.

[5]柏原士郎, 上野淳, 森田孝夫。阪神・淡路大震灾た打ける避难所の 研究 [M]. 大阪: 大阪大学出版社, 1998.

[6]防災訓練に伴う園地の使用について（打願い）[EB/OL]. 東京臨海広 域防災公園 . (2015-11-06). http://www.ktr.mlit.go.jp/showa/tokyorinkai/ news/news_790.htm.

[7]国土交通省。国土数值情報, 都市公園データ [EB/OL]. 地理情報 システム(GIS). (2015-09-28). http://nlftp.mlit.go.jp/ksj/gml/datalist/ KsjTmplt-P13.html.

[8] 陈静, 翟国方, 陈昭。日本《海啸防灾地区建设法》引介 $[J]$. 国际城市 规划, 2014(1): 123-126.

[9] おいらせ町津波避難計画 [R]. おいらせ町, 2014.

[10] 国土交通省，都市局，都市安全課。津波防災まちづくりの計画策定 に係る指針 [R]. 街路交通施設課, 2013.

[11] Kyodo. Tsunami Hit More than 100 Designated Evacuation Sites [EB/ OL]. The Japan Times, (2011-04-14). http://www.japantimes.co.jp/text/ nn20110414a4.html.

[12] Stuart Fraser, Alison Raby, Antonios Pomonis, et al. Tsunami Damage to Coastal Defences and Buildings in the March 11th 2011 Mw 9.0 Great East Japan Earthquake and Tsunami[J]. Bulletin of Earthquake Engineering, 2013, 11(1): 205-239.

[13] Stefan J Scheer, Vassiliki Varela, George Eftychidis. A Generic Framework for Tsunami Evacuation Planning[J]. Physics and Chemistry of the Earth, 2012(49): 79-91.

[14] 東日本大震災における学校等の対応等に関する調査報告書 $[R]$. 文部 科学省, 2012 .

[15] 李粀玥, 牛品一, 顾朝林. 弹性城市研究框架综述 [J]. 城市规划学刊, 2014(5): 23-31.

[16] 屈凌燕, 岳德亮, 等。“灿鸿” : 50 年来同期最强台风袭浙江 [EB/OL] 新华网. (2015-07-11). http://news.hexun.com/2015-07-11/177469890. html?from=rss.

[17] 佚名. 台风“灿鸿”预计下午登陆浙江 90 万人疏散 [EB/OL]. 凤風网, (2015-07-11). http://v.ifeng.com/news/mainland/201507/01742983-37774b05-acca-7167ed1ac81a.shtml.

[18] 天津市地震局。天津市应急避难场所分布 [ EB/OL]. 天津市地 震信息网 . (2012-03-07). http://www.eq-tj.ac.cn/index/ztlm/fwrx/ rxxw/20120307033127887qbM.shtml.

[19] 上海市园林设计院有限公司, 上海现代建筑设计（集团）有限公 司.上海市应急避难场所设计规范 [EB/OL]. http://wenku.baidu.com/ view/1869a3b63968011ca30091d8.html?pn=50.

[20] 上海市人民政府.上海市突发事件人员疏散撤离和避难场所启用 应急预案 (2015 版) [EB/OL]. (2015-07-11). http://www.shanghai.gov. cn/shanghai/node2314/node2319/n31973/n32019/n32022/n32025/ u21ai858111.shtml.

[21]深圳市规划和国土资源委员会. 深圳市应急避难场所专项规划 (2009-2020) [EB/OL]. (2009-12). http://wenku.baidu.com/view/ af5a012458fb770bf78a5511.html.

[22] 苏幼坡. 城市灾害避难与避难疏散场所 [M]. 中国科学技术出版社, 2006 .

[23] 王漟, 曾坚. 城镇化进程中沿海城市避难疏散场所规划研究 [J]. 建筑学 报 (S2), 2014(12): 37-39.

[24] 戴慎志. 城市综合防灾规划 [M]. 中国建筑工业出版社, 2011.

(本文编辑：胡文娜) 